\title{
The need for better management and control of POPs stockpiles
}

\author{
Roland Weber $^{1,2} \cdot$ Margret Schlumpf $^{3} \cdot$ Takeshi Nakano $^{4,5} \cdot$ John Vijgen $^{1}$
}

Received: 26 July 2015 / Accepted: 4 August 2015 / Published online: 19 September 2015

(C) Springer-Verlag Berlin Heidelberg 2015

This special issue of ESPR includes selected papers from the 12th Forum of the International $\mathrm{HCH}$ and Pesticides Association (IHPA) (Vijgen et al. 2015) as well as selected contemporary case studies on persistent organic pollutants (POPs). Core IHPA themes (www.ihpa.info) addressed in this issue include the management of pesticide/POPs stockpiles (Van Thuong et al. 2014; Pieterse et al. 2015; Vijgen et al. 2011); pollution by $\mathrm{HCH}$ and other POPs at former production site (Amirova and Weber 2015; Torres et al. 2013; Wimmerová et al. 2015; Wycisk et al. 2013); and actions and proposals for moving towards solutions for legacy POPs contamination (Vijgen et al. 2013).

A special session at the 12th Forum addressed the health consequences of pesticides and related POPs further contributing to recent review on the estimated external cost of endocrine disrupting chemicals in the EU (157 Billion Euro/year) with the largest effect estimated from pesticides (Trasande et al. 2015). The papers published in this special issue demonstrate that low levels of pesticides can significantly alter

Responsible editor: Philippe Garrigues

Roland Weber

roland.weber10@web.de

John Vijgen

john.vijgen@ihpa.info

1 International $\mathrm{HCH}$ and Pesticides Association, Elmevej 14, DK-2840 Holte, Denmark

2 POPs Environmental Consulting, Lindenfirststr. 23, D-73527 Schwäbisch Gmünd, Germany

3 GREEN Tox GmbH, Langackerstrasse 49, CH-8057 Zürich, Switzerland

4 Research Center for Environmental Preservation, Osaka University, Osaka, Japan

5 Hyogo Environmental Advancement Association, Kobe-shi, Japan concentrations of hormones in children and influence sexual maturation (Croes et al. 2014); result in a developmental disorder (Sisto et al. 2015) induce liver diseases (Carvalho et al. 2014); and cancer (Porta 2014). Another study shows the influence of Dioxin on sperm quality (Galimova et al. 2014).

Key conclusions from the 12th Forum were compiled in a consensus statement called the Kiev Declaration (IHPA 2013; Vijgen et al. 2015).

In this editorial, we particularly want to highlight the scale of the contemporary challenge for the safe management and effective destruction of POPs and associated contamination in industrial countries; the slow progress in addressing PCB stockpiles and contamination in developing countries; and, as new POPs are added to the Stockholm Convention, the increasing stockpiles of POPs now including brominated flame retardants (PBDEs, HBCD and HBB) and PFOS and related precursors as first perfluorinated alkylated substances (PFASs) which must be addressed. Progress in dealing with the POPs originally listed in the convention has been painfully slow, and it is vital that together we should find a better way forward.

Three recent examples with some widespread contamination highlighted in the selected case-studies show how even industrial countries with adequate destruction capacity of modern technology and a well-established regulatory framework - including clear lines of responsibility for the competent authorities - can still struggle to manage POPs in an environmentally sound, manner. The first case, described by Lysychenko et al. (2015)), details how the government of Ukraine excavated approximately 20,000 t of "HCB waste" from a large, poorly engineered, landfill in which it had been dumped during 30 years of organochlorine solvent production. The waste followed the common route of being exported for destruction by hazardous waste incineration in Europe and much of it was accepted by a Polish operator. The Polish incineration facility, however, was not appropriate for dealing 
with this quantity of POPs waste as can be seen in a film made by Polish journalists which clearly shows how the incineration facility was unable to handle and store the POPs waste safely (http://uwaga.tvn.pl/reportaze,2671,n/the-carcinogenic-hcbby-the-baltic-sea, 135689.html). Thousands of tonnes of POPs waste, some in partly torn "big bags" were just piled outside and only approximately $100 \mathrm{~m}$ from the Baltic Sea. Some of the toxic ash from the incinerator was dumped in a local gravel pit with a high water table but without any engineering or environmental protection measures. The capacity of the incinerator was limited, and the HCB waste is still processed more than 3 years after the waste was received. The case is currently being investigated by a state prosecutor and the company, which is owned by a German investor, needed to build an appropriate storage facility. Ironically the official responsible for issuing the permit for the import of this POPs waste was the current president of the Basel Convention responsible for the safe transboundary movement of hazardous waste and its environmentally sound management ${ }^{1}$.

A second contemporary case of $\mathrm{HCB}$ waste excavated from an organochlorine production site in Austria has caused widespread contamination of both the environment and of local residents through contaminated food as a consequence of releases of HCB during "destruction" in a cement kiln (Funk et al. 2015; Lysychenko et al. 2015). The HCB waste was fed into the cement kiln at temperatures which were too low and some was released, unburned, into the atmosphere. By this release, the Görtschitztal valley in Kärnten has been contaminated with HCB being found in fodder, cattle, milk and humans (Funk et al. 2015). By March 2015, it was reported that 289 cattle and $800 \mathrm{t}$ of milk had been destroyed and approximately 40,000 t of contaminated fodder (e.g. harvested grass) from 332 farms had been removed and stored for further treatment (Der Kurier 2015; Funk et al. 2015). An investigation of the case by the "Funk-Commission" concluded that the feeding of the cement kiln with HCB waste and the associated releases took place over 10 to 13 months and was due to failures by the cement company and also due to a lack of effective control by the competent authority (Funk et al. 2015). This case is also being investigated by the state prosecutor, and it will be interesting to see which stakeholders have to pay for the extensive damage to the valley and whether any compensation is extracted to cover the costs of the contamination of humans, animals and food.

The third case, also currently being dealt with by the courts, relates to the managers of the German company ENVIO, one of the companies active globally in the management of PCBs, who are accused of having damaged the environment and the health of their employees. The company was DIN EN ISO 14001 certified, had a German licence for hazardous waste management and had received an environmental award

\footnotetext{
${ }^{1}$ See the documentary film from minute 38 on.
}

shortly before the contamination was revealed. In spite of this, the company contaminated their factory area and the staff at their headquarters in Germany as a result of inadequate controls on the handling, operation, maintenance, storage and safety measures at the sites. Staff working at the factory was heavily contaminated with 349 having elevated blood levels of PCBs ( $>95$ th percentile for at least one of the measured congeners) and blood concentration up to $376 \mu \mathrm{g} / \mathrm{l}(6$ Indicator-PCBs) (Bullerdieck 2011). Investigations into the case revealed a range of failures by the competent authorities (Hoffmeister et al. 2011) these included announcement of all inspections to the company in advance which is, worryingly, an increasingly common practice by modern regulators. Further details are available from the website of a German media organisation (http://envio.derwesten.de/).

These three contemporary cases of mismanagement of POPs in industrial countries demonstrate:

- Even in industrial countries, the regulatory framework for the management and control of POPs is not always effective and appropriately implemented. This can lead to contamination of the environment and adverse impacts on humans. In each case, the lax control by competent authorities (including in one case the president of the Basel Convention1) was a contributory factor to the contamination.

- The DIN EN ISO 14001 accreditation was relied upon by the regulatory authorities to relax controls (Hoffmeister et al. 2011) and therefore contributed to the POP contamination. Strict monitoring and review by competent authorities are essential and require professional, well informed and technically competent regulatory authorities.

- The contamination of feed, food, humans and the environment associated with the purported "destruction" of $\mathrm{HCB}$ waste in the Austrian cement kiln reaffirms the need for continuous monitoring and careful supervision of POPs destruction projects including long-term emission monitoring (Reinmann et al. 2010; Weber 2007).

- The three examples all relate to the EU, and it is clear that inadequate resources and attention are currently being allocated to the implementation of the Stockholm Convention. Also e-waste including brominated POPs end up in developing countries (Sindiku et al. 2014; Sindiku et al. 2015; Babayemi et al. 2014).

- Ultimately, the only long-term solution to the hazards of POPs is to ensure that the obligations of the Stockholm Convention to destroy or irreversibly transform the POPs are strictly applied - including the use of precautionary concentration thresholds for the lower bounds of destruction (the "low POPs" levels).

It is clear from the recent UNEP status report on the global management of PCB stockpiles prepared for the 7 th Conference of Parties of the Stockholm Convention in 
May 2015 (UNEP 2015) that the international community is really only in the early stage of grappling with the real issues associated with the effective management and destruction of POPs stockpiles. The UNEP inventory estimates that only between 1.6 and 3.1 million tonnes of PCBs and associated wastes have yet been managed whilst the c. 9.3 million tonnes of PCB equipment and materials/oils still needs to be eliminated (UNEP 2015).

Also, the development of a UNDP/UNIDO/GEF project to destroy POPs stockpiles and deposits with noncombustion technologies at the former PCB production site in Slovakia (IHPA 2006) failed the last decade, and the study of Wimmerová et al. (2015) highlight the contemporary risk of $\mathrm{PCB}$ at this site and its impact on the population in more than $50-\mathrm{km}$ distance. Kawamoto et al. (2014) describe the dioxin formation and control of a non-combustion technology.

Furthermore, PCB stocks are just the tip of the POPiceberg when the volumes of newly listed POPs waste are taken into account-including the 4 to 7 million tonnes of $\mathrm{HCH}$ waste isomers from lindane production (Vijgen et al 2011) and the enormous volumes of waste impacted by the first brominated flame retardants now listed as POPs in the Stockholm Convention (PBDEs, HBCD, HBB). This issue of ESPR contains the first review of the monitoring, inventory and related material/substance flows for PBDE in a developing country (Nigeria) (Babayemi et al. 2014; Sindiku et al 2014). This study shows that c. $2300 \mathrm{t}$ of c-OctaBDE is contained in the approximately 2.4 million tonnes of plastics imported with electronics and e-waste to Nigeria since 2000 (Babayemi et al. 2014). Alarmingly, alone the $237,000 \mathrm{t}$ of CRT casings of this e-waste plastic stockpile is estimated to contain between 2 and $8 \mathrm{t}$ of brominated dioxins and furans (PBDD/F)! ${ }^{2}$ (Sindiku et al. 2015). Current waste management practices including open burning, dumping and uncontrolled recycling inevitably result in environmental and human contamination (Babayemi et al. 2014). The challenges that have been highlighted with the management of these POPs stockpiles reaffirm the recommendation made by the Stockholm Convention's POP Review Committee for the (then) new listed POP-PBDEs (UNEP 2010). The Committee recommended that countries being in the position to separate plastics, and particularly industrial countries, should eliminate PBDEs as soon as possible rather than allowing them to be included in recycled products (UNEP 2010). However, it has

\footnotetext{
${ }^{2}$ One contribution in this special issue revealed that $\mathrm{PBDD} / \mathrm{F}$ are even formed when fish containing DecaBDE are heated to $200{ }^{\circ} \mathrm{C}$ (Vetter et al. 2014).
}

been revealed over the last decade that such POP waste is frequently exported to developing countries (Breivik et al. 2011; Baldé et al. 2015) with limited capacity to handle the waste safely. The inevitable consequence has been that the recycling of POPs, such as those contained in WEEE plastics, has caused extensive contamination of sites in developing and in transition countries (Labunska et al. 2014; Weber et al. 2008). This contamination continues today.

Last, but certainly not least, the first published inventory of PFOS and related precursors-listed as first per- and polyfluorinated alkylated substances (PFAS) in the Stockholm Convention - have shown that even in an industrialized country such as Turkey PFOS in articles and products has proved to be virtually untrackable with current regulatory approaches (Korucu et al. 2014). The clear conclusion of the study is that improvements are needed to the regulatory framework and controls for POPs and POPs-like substances (including other hazardous chemicals) in products and articles (Korucu et al. 2014).

Taken together, these studies echo our editorial from the last special ESPR issue by emphasising that a more integrated approach to the global management of POPs is required (Weber et al. 2013). Reductions in the levels of unintentionally produced POPs in current products (addressed in this special issue by Anezaki et al. 2014; Huang et al. 2014a, b) and highlighted for chemical production in China by Nie et al. (2014) should be an immediate goal. In the medium term, we need to substitute the listed POPs as well as the (several hundred) POPs-like substances in current use (Scheringer et al. 2012; Muir and Howard 2006) with more sustainable alternatives. In the medium to long term, we must aspire to the complete elimination of POPs as promised by the Stockholm Convention. Doing so will require far more effort and resources than has previously been allocated to the control and management of hazardous chemicals.

\section{References}

Amirova Z, Weber R (2015) Massive PCDD/F Contamination at the Khimprom organochlorine plant in Ufa - A review and recommendations for future management. Environ Sci Pollut Res Int. doi: 10. 1007/s11356-015-5048-8

Anezaki K, Kannan N, Nakano T (2014) Polychlorinated biphenyl contamination of paints containing polycyclic- and Naphthol AS-type pigments. Environ Sci Pollut Res Int. doi: 10.1007/s11356-0142985-6

Babayemi J, Sindiku O, Osibanjo O, Weber R (2014) Substance flow analysis of polybrominated diphenyl ethers in plastic from EEE/ WEEE in Nigeria in the frame of Stockholm Convention as a basis 
for policy advice. Environ Sci Pollut Res Int. doi: 10.1007/s11356014-3228-6

Baldé CP, Wang F, Kuehr R, Huisman J (2015) The global E-waste monitor 2014. United Nation University

Breivik K, Gioia R, Chakraborty P, Zhang G, Jones KC (2011) Are reductions in industrial organic contaminants emissions in rich countries achieved partly by export of toxic wastes? Environmental Science \& Technology 45(21):9154-9160

Bullerdieck U (2011) Ergebnisse im Überblick-Vergleich Envio / Nachbarfirmen. Pressestelle der Stadt Dortmund

Carvalho DF, Guimarães MT, Ribeiro TS, Campina NN, Lobarinhas MR, Lopes AL, Cunha MG, Souza IB, Oliveira VL, Braga E Braga L, Martins LC, Gomes A, Pereira LA, Braga AL (2014) Prevalence of liver diseases as referred by people living in the Santos and São Vicente Estuary. Environ Sci Pollut Res Int. doi: 10.1007/s11356014-3073-7

Croes K, Den Hond E, Bruckers L, Govarts E, Schoeters G, Covaci A, Loots I, Morrens B, Nelen V, Sioen I, Van Larebeke N, Baeyens W (2014) Endocrine actions of pesticides measured in the Flemish Environment and Health Studies. Environ Sci Pollut Res Int. doi: 10.1007/s11356-014-3437-z

Der Kurier (2015) HCB-Skandal sprengt Landesbudget., 24.03.2015

Funk B-C, Hutter H-P, Neubacher F, Raschauer B (2015) HCB-Belastung Görtschitztal / Kärnten Verfahrenstechnische - juristische medizinische Beurteilung

Galimova EF, Amirova ZK, Galimov SN (2014) Dioxins in the semen of men with infertility. . Environ Sci Pollut Res Int. doi: 10.1007/ s11356-014-3109-Z

Hoffmeister J, Ley S, Schütz N, Birnstengel B, Alwast H, Buchholz G (2011) Der Fall ENVIO/Dortmunder Hafen - Klärung weiterer Fragestellungen mit immissionsschutzrechtlichem und abfallwirtschaftlichem Hintergrund. Abschlussbericht., p 137

Huang J, Gao J, Yu G, Yamazaki N, Deng S, Wang B, Weber R (2014a) Unintentional formed PCDDs, PCDFs, and DL-PCBs as impurities in Chinese pentachloronitrobenzene products. Environ Sci Pollut Res Int. doi: 10.1007/s11356-014-3507-2

Huang J, Yu G, Yamauchi M, Matsumura T, Yamazaki N, Weber R (2014b) Congener-specific analysis of polychlorinated naphthalenes (PCNs) in the major Chinese technical PCB formulation from a stored Chinese electrical capacitor. Environ Sci Pollut Res Int. doi: 10.1007/s11356-014-3677-y

IHPA (2006) Project 1: UNIDO signs US\$20 million UNDP/GEF/ UNIDO POPs project. POPs and obsolete Pesticide Newsletter


POPs-Newsletter-No11. http://www.ihpa.info/docs/newsletters/ IHPA-POPs-Newsletter-No11.pdf

IHPA (2013) Key messages $12^{\text {th }}$ International HCH and pesticide Forum. Kiev, 6-8 November 2013., http://www.hchforum.com/12th/ conclusions.php

Kawamoto K (2014) Dioxin formation and control in a gasificationmelting plant.. doi:10.1007/s11356-014-3104-4

Korucu MK, Gedik K, Weber R, Karademir A, Kurt-Karakus PB (2014) Inventory development of perfluorooctane sulfonic acid (PFOS) in Turkey: challenges to control chemicals in articles and products. Environ Sci Pollut Res Int. doi: 10.1007/s11356-014-3924-2

Labunska I, Harrad S, Wang M, Santillo D, Johnston P (2014) Human dietary exposure to PBDEs around E-waste recycling sites in Eastern China. Environ Sci Technol 48:5555-5564

Lysychenko G, Weber R, Gertsiuk M, Kovach V, Krasnova I (2015) Hexachlorobenzene waste deposits at Kalush city (Ukraine) Threat to Western Ukraine and transboundary water bodies and remediation efforts. Environ Sci Pollut Res Int. doi:10.1007/s11356015-5184-1

Muir DC, Howard PH (2006) Are there other persistent organic pollutants? A challenge for environmental chemists Environ Sci Technol 40:7157-7166
Nie Z, Fang Y, Tian S, Yang Y, Die Q, Tian Y, Liu F, Wang Q, Huang Q (2014) Perspective on polychlorinated dibenzo-p-dioxin and dibenzofuran emissions during chemical production in China: an overlooked source of contemporary relevance. Environ Sci Pollut Res Int. doi: 10.1007/s11356-014-3801-z

Pieterse B, Rijk IJC, Simon E, van Vugt-Lussenburg BMA, Fokke BFH, van der Wijk M, Besselink H, Weber R, van der Burg B (2015) Effect-based assessment of persistent organic pollutant- and pesticide dumpsite using mammalian CALUX reporter cell lines. Environ Sci Pollut Res Int. doi: 10.1007/s11356-015-4739-5

Porta M (2014) Human contamination by persistent toxic substances: the rationale to improve exposure assessment. Environ Sci Pollut Res Int. doi: 10.1007/s11356-014-3460-0

Reinmann J, Weber R, Haag R (2010) Long-term monitoring of PCDD/ PCDF and other unintentionally produced POPs - Concepts and case studies from Europe. Science in China - Chemistry 53:10171024

Scheringer M, Strempel S, Hukari S, Ng CA, Blepp M, Hungerbühler K (2012) How many Persistent Organic Pollutants should we expect? Atmospheric Pollution Research 3:383-391

Sindiku O, Babayemi J, Osibanjo O, Schlummer M, Schluep M, Watson A, Weber R (2014) Polybrominated diphenyl ethers listed as Stockholm Convention POPs, other brominated flame retardants and heavy metals in E-waste polymers in Nigeria. Environ Sci Pollut Res Int. doi: 10.1007/s11356-014-3266-0

Sindiku O, Babayemi JO, Tysklind M, Osibanjo O, Weber R, Watson A, Schlummer M, Lundstedt S (2015) Polybrominated Dioxins and Furans $(\mathrm{PBDD} / \mathrm{Fs})$ in e-waste plastics in Nigeria. Environ Sci Pollut Res Int. doi:10.1007/ s11356-015-5260-6

Sisto R, Moleti A, Palkovičová Murínová L, Wimmerová S, Lancz K, Tihányi J, Čonka K, Šovčíková E, Hertz-Picciotto I, Jusko TA, Trnovec T. (2015) Environmental exposure to organochlorine pesticides and deficits in cochlear status in children. Environ Sci Pollut Res Int. doi:10.1007/s11356-015-4690-5

Trasande L, Zoeller RT, Hass U, Kortenkamp A, Grandjean P, Myers JP, DiGangi J, Bellanger M, Hauser R, Legler J, Skakkebaek NE, Heindel JJ (2015) Estimating burden and disease costs of exposure to endocrine-disrupting chemicals in the European Union. J Clin Endocrinol Metab 100:1245-1255

Torres JPM, Fróes-Asmus CIR, Weber R, Vijgen JMH (2013) Status of $\mathrm{HCH}$ contamination from former pesticide production and formulation in Brazil - a task for Stockholm Convention Implementation. Environ Sci Pollut Res Int 20:1951-1957

UNEP (2010) Annex to decision POPRC-6/2 Recommendations on the elimination of brominated diphenyl ethers from the waste stream and on risk reduction for perfluorooctane sulfonic acid (PFOS) and its salts and perfluorooctane sulfonyl fluoride (PFOSF). UNEP/POPS/POPRC.6/13

UNEP (2015) Preliminary assessment of efforts made toward the elimination of polychlorinated biphenyls UNEP/POPS/COP.7/INF/9

Van Thuong N, Hung NX, Mo NT, Thang NM, Huy PQ, Van Binh H, Nam VD, Van Thuy N, Son LK, Minh NH. (2014) Transport and bioaccumulation of polychlorinated dibenzo-p-dioxins and dibenzofurans at the Bien Hoa Agent Orange hotspot in Vietnam. Environ Sci Pollut Res Int. doi: 10.1007/s11356-014-3946-9

Vetter W, Bendig P, Blumenstein M, Hägele F, Behnisch PA, Brouwer A (2014) Formation of polybrominated dibenzofurans (PBDFs) after heating of a salmon sample spiked with decabromodiphenyl ether (BDE-209). Environ Sci Pollut Res Int. doi: 10.1007/s11356-0143267-z

Vijgen J, Abhilash PC, Li Y-F, Lal R, Forter M, Torres J, Singh N, Yunus M, Tian C, Schäffer A, Weber R (2011) HCH as new Stockholm Convention POPs - a global perspective on the management of Lindane and its waste isomers. Env Sci Pollut Res Int 18:152-162 
Vijgen J, Aliyeva G, Weber R (2013) The forum of the International HCH and pesticide association - a platform for international cooperations. Environ Sci Pollut Res Int 20:1901-1906

Vijgen J, Malkov M, Păun MC, Weber R (2015) The 12th International $\mathrm{HCH}$ and Pesticides Forum in Kiev/Ukraine. Environ Sci Pollut Res Int 22:4780-4785

Weber R (2007) Relevance of PCDD/PCDF formation for the evaluation of POPs destruction technologies-Review on current status and assessment gaps. Chemosphere 67:109-117

Weber R, Gaus C, Tysklind M, Johnston P, Forter M, Hollert H, Heinisch E, Holoubek I, Lloyd-Smith M, Masunaga S, Moccarelli P, Santillo D, Seike N, Symons R, Torres J, Verta M, Varbelow G, Vijgen J, Watson A, Costner P, Woelz J, Wycisk P, Zennegg M (2008) Dioxin- and POP-contaminated sites-contemporary and future relevance and challenges. Environ Sci Pollut Res Int 15:363-393

Weber R, Aliyeva G, Vijgen J (2013) The need for an integrated approach to the global challenge of POPs management. Environ Sci Pollut Res Int 20:1901-1906, http://link.springer.com/content/pdf/10. 1007\%2Fs11356-012-1247-8.pdf

Wimmerová S, Watson A, Drobná B, Šovčíková E, Weber R, Lancz K, Patayová H, Jurečková D, Jusko TA, Murínová L, Hertz-Picciotto I, Trnovec T (2015) The spatial distribution of human exposure to PCBs around a former production site in Slovakia. Environ Sci Pollut Res Int. doi:10.1007/s11356015-5047-9

Wycisk P, Stollberg R, Neumann C, Gossel W, Weiss H, Weber R (2013) Integrated Methodology for Assessing the $\mathrm{HCH}$ Groundwater Pollution at the Multi-Source Contaminated Mega-Site Bitterfeld/Wolfen. Env Sci Pollut Res Int 20: $1907-1917$

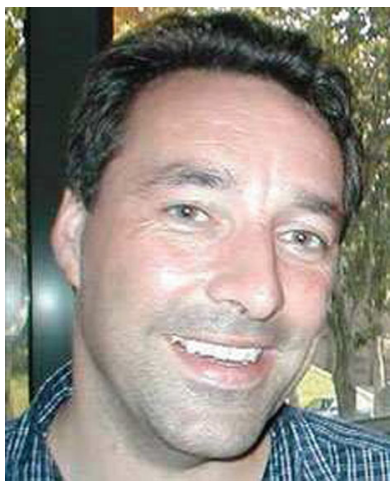

Roland Weber is working since 2003 as an independent international consultant for a number of UN Organisations (UNIDO, UNDP, UNEP) and environmental ministries for the implementation of the Stockholm Convention on Persistent Organic Pollutants (POPs) and synergies to other conventions. His areas of expertise include dioxins, other unintentionally produced POPs and newly listed POPs such as brominated POPs, PFOS and lindane/HCHs. He received his $\mathrm{PhD}$ in 1996 from Tübingen University and worked from 1997-2002 as head of a Dioxin/ POPs R\&D laboratory for IHI Co Ltd. (Yokohama/Japan) with research links to Kyoto and Ritzumeikan Universities. Since 20 years he is an active member of the "global POPs research community" and has published more than 100 peer reviewed papers in this field. He is drafter/ author of several technical guidance papers for the Stockholm Convention. Since two years he is member of the expert group for the EU project on sustainable consumption and production in the Mediterranean (www. switchmed.eu). Dr. Weber is since 2010 a visiting Professor at the Tsinghua University POPs Research Centre in Beijing. He serves as a member of the Editorial Board of ESPR and edits a series on POPs contaminated sites. He is also an ambassador for the International $\mathrm{HCH}$ \& Pesticide Association (www.ihpa.info), a member of the International Panel on Chemical Pollution (www.ipcp.ch) and board member of two NGOs promoting sustainable lifestyles (www.nachhaltig.at; www. andersbesser-leben.de).

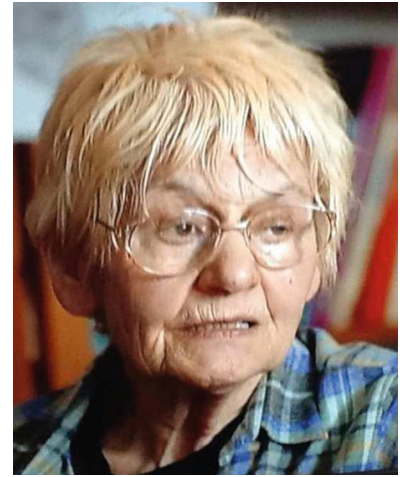

Margret Schlumpf Following the Swiss Stateboard Exam in Pharmacy (ETH) Margret Schlumpf joined the Institute of Pharmacology at the University of Zurich and ETH, organizing a student practicum in Pharmacology and Toxicology. With her doctoral degree on a "micro method for the analysis of the neurotransmitters dopamine, noradrenaline and adrenaline in defined small regions of rat and mouse brain" at hand and funded by Swiss National Foundation for Scientific Research, she left Europe and moved to the National Institute of Mental Health at St. Elizabeth's Hospital, joining the Laboratory of Neuropharmacology in Washington (D.C.) Following 2 years of research she continued at the Arthur Vining Davies laboratory for Behavioral Neurobiology at the Salk Institute in La Jolla, California and pursued her in vivo and in vitro studies on the ontogeny of these brain neurotransmitters in embryonic and fetal rat brain at the Institute of Pharmacology and Toxicology in Zürich. Ultimately this work was done together with the newly founded GREEN Tox group (http://www.greentox.org/), where she and the team was engaged in studies on effects of heavy metals and environmental chemicals (nicotine, diazepam and cosmetics, namely perfumes and UV filters) on the developing brain. Her private docent thesis was on" Developmental Neuro-immune-toxicology of diazepam".

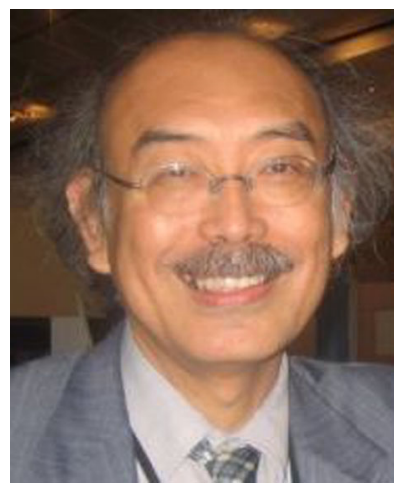

Dr. Takeshi Nakano obtained a masters degree in Applied Chemistry from Osaka University, Japan, in 1974, and a Ph.D. at the same University (Studies on CongenerSpecific Analysis of Chlorinated Aromatics and its Application to Environmental Chemistry ) in 2007. In 1974 he joined the Hyogo Prefectural Institute of Environmental Science for more than 40 years. He contributed to the field of congener-specific analysis for Dioxin and related compounds. His main expertise is in the field of Persistent Organic Pollutants (POPs), especially Dioxins and Furans as well as PCBs in human and environmental samples. His expertise is also in the field of enantioselective analysis for chiral chemicals such as PCB, HCH, DDT, Chlordanes. Dr. Nakano has authored more than 60 scientific publications. He is contributing to various POPs related committees under the Ministry of Environment of Japan such as POPs monitoring, PCB destruction project, unintentional formation of POPs. $\mathrm{He}$ organized the International Conference of Asian Environmental Chemistry in 2014 and will organize The 9th PCB Workshop in 2016 in Kobe Japan. Since 2014, he is contributing to the JICA (executing agency for technical cooperation of the Government of Japan) grass root project "Capacity Building for Analysis and Reduction Measures of Persistent Organic Pollutants in Serbia" as project leader. He maintains voluntary web-server for sharing information of environmental, analytical, technical issue as chief member of the MS analysis commission of the Japanese water environment society. His hobby is to record researcher's natural smile as official photographer of the Dioxin Conference series (http:// www.ee-net.ne.jp/dioxin/index.html) and other Conferences. 




John Vijgen, born in 1951 in Heerlen, The Netherlands and was educated as civil engineer at the Technical University of Aachen, Germany. He has been working for more than 40 years on the clean-up of contaminated sites and pesticide stockpiles including the elimination of 200,000 tonnes of HCH and Lindane contaminated soils and wastes when working for TAUW. At present he is director of the International $\mathrm{HCH} \&$ Pesticides Association (IHPA; www.ihpa.info), which he founded in 1998 with the objective of eliminating obsolete pesticides in Central and Eastern Europe, the Caucasus and the Central Asia Republics (EECCA). Over more than 23 years, he has been organizing the biannual International $\mathrm{HCH}$ and Pesticides Forum including the 2013 forum in Kiev/Ukraine and the upcoming in Zaragoza in Spain 3-6 November 2015 (http://www. hchforum.com/). The Forum provides an international platform to solve obsolete pesticides problems, brings stakeholders together to exchange experiences, involves donors, public and private problem owners, scientists and civil society and dedicated politicians. In 2006, he published "The Legacy of Lindane HCH Isomer Production", a major contribution for the nomination of Lindane and $\mathrm{HCH}$-isomers as POP in the framework of the Stockholm Convention. He was involved in a large number of pesticides cleanups and has recently produced for UNEP 18 new Fact sheets for POPs destruction technologies that will be published before the end of 2015. From 2009 to 2013, with Green Cross and Milieukontakt Int., he has been managing the GEF-FAO project on capacity building on obsolete and POPs pesticides in EECCA countries. At present, he is finalizing within the EU financed and by FAO managed project on "Improving capacities for obsolete pesticides in the Former Soviet Union" the report "Road Map to Establishing Environmental Sound Management of POPs Pesticides and other Hazardous Waste in the EECCA region" plus national waste management and legal reports for the 12 countries that will be published towards the end of 2015 . 